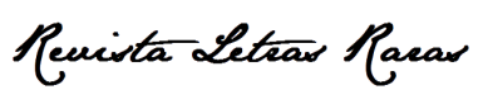

ISSN: 2317-2347 - v. 9, n. 4 (2020)

Todo o conteúdo da RLR está licenciado sob Creative Commons Atribuição 4.0 Internacional

\title{
The processing of typological similar languages among trilingual speakers of Spanish, English and Portuguese /
}

\section{O Processamento Lexical de línguas tipologicamente próximas entre falantes trilíngues de Espanhol, Inglês e Português}

\begin{abstract}
Jamile Forcelini *
Jamile Forcelini has a PhD in Hispanic Linguistics from Florida State University. Originally from Brazil, Dr. Forcelini taught a variety of classes in Spanish, Portuguese, ESL and Linguistics in the past. Her research investigates bilingual and trilingual lexical processes and instruction on lexical processing and acquisition.
\end{abstract}

\section{http://orcid.org/0000-0001-7054-1839}

Received: October, 05th, 2020. Approved: November, 04th, 2020.

How to cite this article:

FORCELINI, Jamile. The processing of typological similar languages among trilingual speakers of Spanish, English and Portuguese. Revista Letras Raras. Campina Grande, v. 9, n. 4, p. 30-42, dez. 2020.

\section{ABSTRACT}

Research shows (VAN HESTE, 1999; VAN HELL; DE GROOT, 1998; VAN HEUVEN, DIJSTRA; GRAINGER, 1998) that when bilinguals process words in one language, shared word features from both languages are also activated. Most lexical processing studies have examined word processing among bilinguals and a smaller subset of studies have focused on word processing among trilinguals. The present study investigates how native and heritage trilingual Spanish speakers process words in comparison to non-native trilingual Spanish speakers. A group of native and heritage trilingual Spanish speakers ( $n=26)$ (L1-Spanish, L2-English and L3-Portuguese) and a group of non-native trilingual Spanish speakers ( $n=40$ ) (First Language (L1) English, Second Language (L2) Spanish and Third Language (L3) Portuguese) visually processed words in different languages (Spanish, Portuguese, German and Basque) and had to determine whether the words they saw were real Spanish words. Reaction times and accuracy were analyzed among both groups and across word type. The goal was to test whether the presence of a third language such as Portuguese would affect processing in a previous known language (first or second language-Spanish). All participants included in this study were at the beginning stages of learning Portuguese as a third language. Results show native/heritage trilingual speakers were able to process words in Spanish faster than nonnative trilingual speakers in addition to processing all word types (in Portuguese, Spanish, German and Basque) more accurately as well. The present findings are analyzed in light of Dijkstra and Van Heuven's (2002) Bilingual Interactive Activation Plus model of word recognition (BIA+).

KEYWORDS: Word processing; Trilingual speakers; Heritage speakers; Portuguese; Spanish.

$\triangle$ jamilemf@yahoo.com 


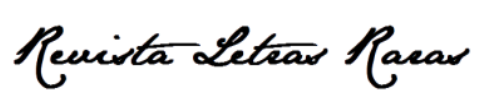

ISSN: 2317-2347 - v. 9, n. 4 (2020)

Todo o conteúdo da RLR está licenciado sob Creative Commons Atribuição 4.0 Internacional

\section{RESUMO}

Pesquisas mostram (VAN HESTE, 1999; VAN HELL; DE GROOT, 1998; VAN HEUVEN, DIJSTRA; GRAINGER, 1998) que, quando falantes bilíngues visualizam palavras em diferentes línguas, diferentes níveis de semelhança lexical fazem com que outros vocábulos sejam simultaneamente ativados. Grande parte das pesquisas em processamento lexical se concentra na população bilíngue; enquanto que poucos estudos analisam tal fenômeno entre falantes trilíngues. O presente estudo se propõe a investigar como falantes trilíngues classificados como falantes nativos e de herança em espanhol processam palavras em diferentes idiomas (espanhol, português, alemão e basco) em comparação com falantes trilíngues não-nativos de espanhol. O objetivo é verificar se o terceiro idioma (português) afeta o processamento lexical em um idioma aprendido anteriormente (espanhol). Dois grupos participaram do estudo. O primeiro grupo era composto por falantes nativos de inglês (L1), com segunda língua espanhol (L2), e terceira língua português (L3). O segundo grupo era composto por falantes trilíngues nativos e/ou de herança em espanhol $(n=26)$ (L1-espanhol, L2-inglês e L3-português). Todos os participantes se encontravam em estágios iniciais de aprendizagem de língua portuguesa (L3). Resultados com base em tempos de reação e precisão demonstraram que falantes trilingues nativos/de herança processaram palavras em espanhol mais rapidamente que falantes trilingues não nativos, além de processar todos os tipos de palavras (em português, espanhol, alemão e basco) com mais precisão. Os presentes resultados se basearam no modelo Bilingual Interactive Activation Plus $(B I A+)$ de Dijkstra e Van Heuven (2002).

PALAVRAS-CHAVE: Processamento lexical; Falantes trilingues; Falantes de herança; Português; Espanhol.

\section{Introduction}

Previous studies have concluded word processing can behave non-selectively (VAN HESTE, 1999; VAN HELL; DE GROOT, 1998; VAN HEUVEN; DIJSTRA; GRAINGER, 1998). This means that when bilinguals covertly read in one of the languages they know (L1 and/or L2), different words from both languages are also and instinctively activated depending on the lexical features they share with the target word. De Groot (2011) claims bilinguals are continuously involved in cognitive activation and suppression processes in order to select the words they wish to use and suppress the token they do not wish to elicit. These skills enable bilinguals to successfully process one language while being able to store more languages in their minds, as depicted by bilingual lexical comprehension models (e.g BIA+) from Dijkstra and Van Heuven (2002). For this reason, it is imperative to explore how specifically one language impacts the other in the bilingual mind and what elements play a stronger role throughout this process.

Besides word formation patterns, different elements also impact word processing among bilinguals such as the proficiency bilinguals have in their $L 2$, as well the linguistic typology languages share. For example, bilinguals whose L1 is Portuguese and L2 is Spanish will present higher levels of lexical activation during word processing because both languages share a wide range of linguistic features, estimated as $89 \%$ of mutual intelligibility across languages (EBERHARD et al., 2020). In terms of linguistic proficiency in L2, the strength of lexical 


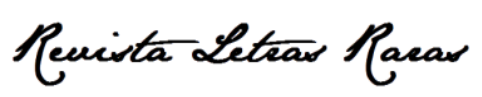

ISSN: 2317-2347 - v. 9, n. 4 (2020)

Todo o conteúdo da RLR está licenciado sob Creative Commons Atribuição 4.0 Internacional

representation in a non-native language may be beneficial so bilinguals are able to isolate a cognitive stimulus and either suppress or activate it depending on the task demand. In other words, lexical strength in $L 2$ enables learners to identify its language membership and therefore decide on a lexical item in a timely manner when processing it.

\section{The BIA + Model}

Several models in psycholinguistics attempt to depict how word activation processes take place in the bilingual mind. One of these models is the Bilingual Interactive Activation Plus model (BIA+) from Dijkstra and Van Heuven (2002). As a successor of the Bilingual Interactive Activation model (BIA) from Van Heuven and Dijkstra (1998), the BIA+ depicts how bilingual lexical comprehension takes place. It includes two interactive (phonologic and lexical) subsystems representing word identification and task/decision. A visual word activates sublexical input representations that lead to the activation of full orthographic representations along with full lexical phonological representations. Semantic representation is then activated leading to the respective language node connection the word belongs. The task demands may be subsequently used to define the reason of elicitation of the target word.

Figure 1 below, which was adapted from Dijkstra and Van Heuven's (2002) BIA+ model, attempts to show the steps a bilingual speaker would go through when processing a word. The first step is triggered by the word input that activates sublexical orthographic and phonological features that compose the word. Following sublexical feature activation, the next step is the activation of full features that compose the word as a whole. In other words, if a bilingual English-Portuguese speaker is visually processing the word "sand" in English, not only neighbors ${ }^{1}$ of the word "sand" in English will be activated, such as "hand", "sane" and "sank", but also cross-language neighbors in Portuguese such as "banda" (band), "santo" (saint) and "tanto" (so much). As bilinguals may be dealing with substantial competition between languages in their lexicon, they may also be able to distinguish the word belonging to one specific language. By doing that, the language the bilingual does not wish to activate (Portuguese in this case) is suppressed and so are all the cross-language neighbors that belong to that language. A bilingual is now fully capable of processing the English word "sand" and its meaning. In the case of trilingual speakers, similar processes would take place,

\footnotetext{
${ }^{1}$ Neighbors are classified as words with shared orthographic and phonological characteristics within the same language or across different languages.
} 


\section{Penista Leteas Paras}

ISSN: 2317-2347 - v. 9, n. 4 (2020)

Todo o conteúdo da RLR está licenciado sob Creative Commons Atribuição 4.0 Internacional

however the degree of crosslinguistic activation would be greater due to the addition of the third language and also due to the degree of lexical overlap among different word types such as cognate 2 and non-cognate words within and across languages.

Figure 1. Adapted from the Bilingual Interactive Activation Plus model (BIA +) from Dijkstra and Van Heuven (2002). Image used for research purpose with appropriate educational objectives in nature, amount, and effect. No copyright required under the guidelines of fair use.

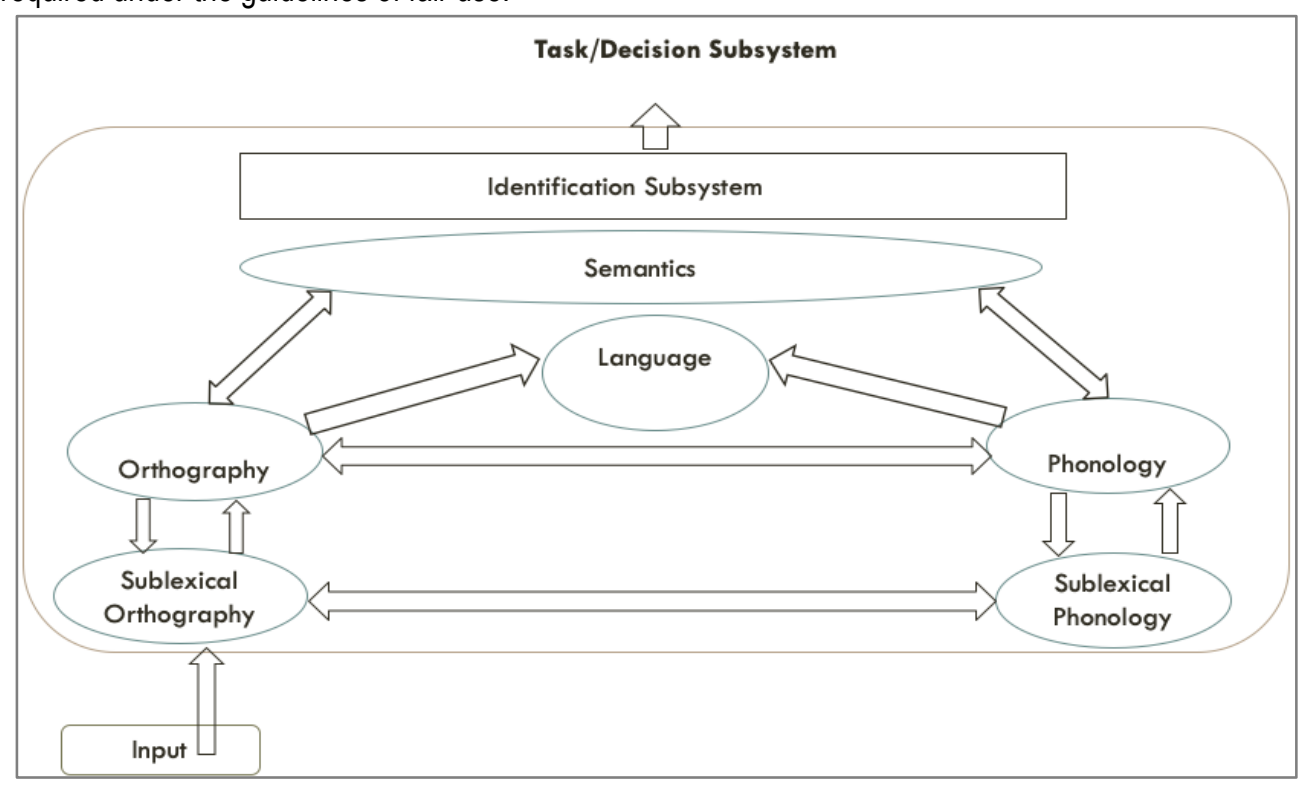

Source: The author.

One of the studies that support the BIA model was conducted by Casaponsa et al. (2015) with Spanish-Basque bilinguals and monolinguals (control) performing a masked priming paradigm. In this task, target words are presented previously to subsequent visual lexical stimuli. Results show a language switch effect for Basque primed words for both bilingual and monolingual groups. Casaponsa et al. (2015) also recognized language switch effects in the bilingual group. These results confirm that lexical orthography plays a key role in bilingual language recognition.

After looking at how bilinguals are able to process words in the mind, it is also important to examine if lexical processes take place similarly in the trilingual mind. Does the increasing number of lexical availability increase the levels of word activation and consequently delays the lexical retrieval process? Does language similarity (linguistic typology) also play a role in this process?

${ }^{2}$ Cognates are words that share form, sound and meaning across different alphabetical languages. 


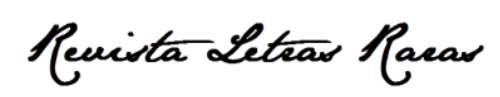

ISSN: 2317-2347 - v. 9, n. 4 (2020)

Todo o conteúdo da RLR está licenciado sob Creative Commons Atribuição 4.0 Internacional

Which language influences the others more? L1, L2 or L3? In which direction does this influence usually take place?

Fewer key studies have looked into word processing among trilinguals in comparison to word processing among bilinguals (VAN HELL; DIJKSTRA, 2002; LEMHOFER; DIJKSTRA; MICHEL, 2004; FORCELINI; SUNDERMAN, FORTHCOMING). Lemhofer, Dijkstra and Michel (2004) looked at group of Dutch-English-German trilinguals performing a lexical decision task (LDT) with "double" cognates (cognates in only two languages) in Dutch and German, "triple" cognates in all three languages as well as control words in German. A lexical decision task asks participants to look at a string of letters in a screen and decide if the word they see is a real word in one of the languages they know. They do that by pressing a key (yes/no) in a keypad. Reaction times and accuracy are measured in this type of task. Participants in this study presented faster RTs when processing double" cognates and even faster RTs when processing "triple" cognates. These results confirm both $\mathrm{L} 2$ and $\mathrm{L} 3$ can affect word processing in L1.

Similarly, Van Hell and Dijkstra (2002) examined a group of Dutch (L1), English (L2), and French (L3) trilinguals at distinct proficiency levels perform different tasks including a lexical decision task in L3 French. The tasks included English and French cognates, noncognates and pseudowords. Results show participants were faster processing Dutch (L1) and English (L2) cognates to French (L3) in comparison to noncognates. These results confirm both L1 (Dutch) and L2 (English) can affect word processing in L3 (French).

Forcelini and Sunderman (forthcoming) looked at a group of English (L1), Spanish (L2) and Brazilian Portuguese (L3) trilinguals at early L2 and L3 proficiency stages. Participants completed a lexical decision task in Spanish (L2) which included double and triple cognates, pseudowords as well as control words in German and Basque. Differently from both studies presented above (VAN HELL; DIJKSTRA, 2002; LEMHOFER, DIJKSTRA; MICHEL 2004), trilinguals were slower to process all words in comparison to bilingual speakers who only knew English (L1) and Spanish (L2). It seems that trilinguals at early stages of $L 3$ learning, present a cognitive lexical cost when trying to process words in $\mathrm{L} 2$ and that this cost may be overcome as proficiency in both nonnative languages ( $\mathrm{L} 2$ and $\mathrm{L} 3$ ) increases.

All three studies looked at lexical processes from different proficiency levels and lexical access directions. Van Hell and Dijkstra (2002) analyzed lexical processing in a progressive manner, which means the effects of L1 towards L2 and L3 were examined. On the other hand, Lemhofer et al. (2004) looked at how the L3 plays a role into previously acquired languages such 


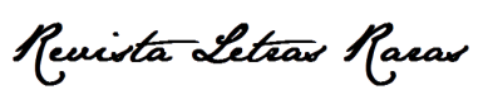

ISSN: 2317-2347 - v. 9, n. 4 (2020)

Todo o conteúdo da RLR está licenciado sob Creative Commons Atribuição 4.0 Internacional

as L2 and L1. What Forcelini and Sunderman (forthcoming) did was to specifically look at the effects of a newly acquired L3 into a previously learned language (L2).

The main goal of this study is to examine how higher proficiency language levels can impact the way trilinguals process words in typological similar languages such as Spanish and Portuguese. Portuguese and Spanish are proto languages, also referred as sister/ sibling languages (MALKIEL, 1941) as they share 89\% of their lexicon that present common morphological and syntactical structures derived from Latin (EBERHARD et al., 2020). Because Forcelini and Sunderman (forthcoming) have showed that trilinguals did not benefit from double and triple lexical activations to process words faster, such advantage may be directly associated with higher proficiency levels in L2 and L3. For that reason, the present study will look at how native and heritage speakers of Spanish whose L2 is English and L3 Portuguese process words in Spanish in comparison to nonnative speakers of Spanish whose L1 is English, L2 is Spanish and L3 is Portuguese. Heritage speakers are known as speakers who have been exposed to a minority language at home since childhood and a majority language at school or another formal education setting (MONTRUL, 2010). For the present study, heritage speakers were exposed to Spanish at home since childhood and later on were exposed to English at the beginning stages of formal education by going to school. As the native/heritage trilingual speakers in this study present higher proficiency levels in Spanish, it is predicted that they will process words in Spanish faster and that the Portuguese (L3) typological similarities will not significantly interfere in this process. In addition, because all participants in this study were still at beginning stages of acquiring Portuguese (L3), it is believed that the $\mathrm{L} 3$ will not affect Spanish word processing as heavily as another more robust language such as L1.

\section{The Present Study}

The current research examines how native and heritage Spanish trilingual speakers who also know English and Portuguese process words in Spanish in comparison to native English trilingual speakers. The objective is to verify whether the different proficiency levels trilingual speakers present in a typological similar language promotes or hinder word processing. Said differently, when trilinguals recognize words in Spanish, what is the impact of also knowing another typologically similar language (L3-Portuguese)? Does the degree of proficiency in Spanish enable learners to better control lexical activation in L3-Portuguese? 


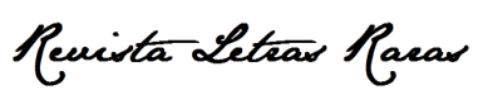

ISSN: 2317-2347 - v. 9, n. 4 (2020)

Todo o conteúdo da RLR está licenciado sob Creative Commons Atribuição 4.0 Internacional

A total of 66 trilingual speakers participated in this study. They were subdivided into two different groups of trilinguals. The first group was formed by English (L1) - Spanish (L2) Portuguese (L3) trilinguals and the second group was formed by Spanish (L1) - English (L2) Portuguese (L3) trilinguals. A total of of 40 participants composed the first group and 26 participants composed the second group.

All participants were currently enrolled in Portuguese language classes in an American university and had been studying Portuguese for up to 3 semesters. A total of 32 self-identified female and 34 self-identified male students whose mean age ranged from 19-39 (21.68) composed both groups 1 and 2 in the study. All participants completed a lexical decision (LDT) task in Spanish followed by a language history questionnaire. For the lexical decision task, participants see a string of letters in a screen and are prompted to determine if the word they see is a real word in one of the languages they have previously learned. They make a choice by using a keypad with two options (yes/no). Reaction times and accuracy are measured in this type of task. For the language history questionnaire, participants answered 23 questions about their age, origin and length of formal education in different languages. They also self-rated their speaking, listening, reading and writing skills in English, Spanish and Portuguese using a Likert scale that ranged from 1 (least proficient) to 10 (extremely proficient).

A one-way ANOVA revealed a significant difference between the proficiency levels reported by native/heritage Spanish and non-native Spanish speakers in both trilingual groups. The analysis revealed a main effect of language status (native/heritage vs. non-native) on both receptive skills: reading at the $p<.05$ level $[F(1,64)=18.85, p<.05]$; and listening $[F(1,64)=35.20$, $p<.05]$. It also reported a main effect on productive skills; writing $[F(1,64)=21.38, p<.05]$; speaking $[F(1,64)=39.47, p<.05]$; and, finally, in overall expression in Spanish $[F(1,64)=44.00, p<.05]$.

Table 1. Self-Rating Means in Spanish for Native/Heritage and Nonnative Trilingual Speakers.

\begin{tabular}{cccccc}
\hline $\begin{array}{c}\text { Self-Reported } \\
\text { Language Skills }\end{array}$ & $\begin{array}{c}\text { Native/ Heritage } \\
\text { Means }\end{array}$ & $\begin{array}{c}\text { Std. } \\
\text { Dev. }\end{array}$ & $\begin{array}{c}\text { Non-Native } \\
\text { Means }\end{array}$ & $\begin{array}{c}\text { Std. } \\
\text { Dev. }\end{array}$ & $p$ \\
\hline Reading in Spanish & 8.64 & 2.15 & 4.69 & 2.84 & $p<.05$ \\
Writing in Spanish & 7.91 & 2.16 & 3.87 & 2.72 & $p<.05$ \\
Speaking in Spanish & 9.18 & 1.07 & 3.80 & 2.78 & $p<.05$ \\
Listening in Spanish & 9.55 & .934 & 4.42 & 2.82 & $p<.05$ \\
Overall Expression & 9.18 & .982 & 3.45 & 2.81 & $p<.05$ \\
\hline
\end{tabular}

Source: The Author (2020). 


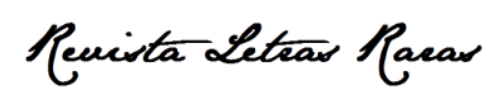

ISSN: 2317-2347 - v. 9, n. 4 (2020)

Todo o conteúdo da RLR está licenciado sob Creative Commons Atribuição 4.0 Internacional

The lexical decision task (LDT) participants had to complete contained a total of 328 words in Spanish (161), Portuguese (96), German (23) and Basque (23). Spanish and Portuguese words were subdivided into Spanish (117) and Portuguese (33) cognates, Spanish (44) and Portuguese noncognates (62) and Spanish (30) and Portuguese (25) pseudowords. Some words included in the stimuli in Spanish were "lunes" (Monday), "natación" (swimming) and "tivera" (pseudoword). Words in Portuguese included "ficar" (to remain), "avião" (airplane), "pitolé" (pseudoword). Words in German and Basque included "gürtel" (belt) and "orain" (now) respectively. The motivation for inserting words in Basque and German into the present experiment lies in the orthographical characteristics of both languages that present distinct patterns of word formation when compared to romance languages such as Spanish and Portuguese.

\section{Results}

A one-way ANOVA was applied in order to compare how both trilingual groups processed words in different languages. Reaction times (RTs) and accuracy were measured. The variables analyzed were word condition $x$ native language (native/heritage speakers of Spanish vs. nonnative speakers). In terms of reaction times, no statistical significance was discovered between both trilingual groups except for Spanish cognate and noncognate words. Native/heritage trilingual speakers demonstrated significantly faster RTs in these conditions. The analysis revealed a main effect of language group on Spanish cognates at the $p<.05$ level for word condition $[F(1,64)=6.96$, $p<.05]$ as well as on Spanish noncognates $[F(1,64)=6.17, p<.05]$. However it did not reveal a significant effect on Portuguese noncognates at the $p<.05$ level $[F(1,64)=4.80, p>.05]$, or Portuguese cognates $[F(1,63)=3.58, p>.05]$. No significant effect was reported for Spanish pseudowords $[F(1,64)=.829, p>.05]$, or Portuguese pseudowords $[F(1,64)=2.78, p>.05]$. Lastly, no significant effects for processing German words were found $[F(1,64)=3.02, p>.05]$, neither for Basque words $[F(1,64)=.992, p>05]$.

To summarize, results show the native/heritage speaker trilingual group processed Spanish words faster than the nonnative trilingual speaker group. However, no differences were seen in the processing of words in Portuguese, German, Basque and either for Spanish or Portuguese pseudowords. 


\section{Penista Leteas Paras}

ISSN: 2317-2347 - v. 9, n. 4 (2020)

Todo o conteúdo da RLR está licenciado sob Creative Commons Atribuição 4.0 Internacional

Table 2. Mean Reaction Times (in $m s$ ) for Native/Heritage and Nonnative Trilingual Speakers by Word Condition.

\begin{tabular}{cccccc}
\hline Word Condition & Nonnative Means & Std. Dev. & Native Means & Std. Dev. & $p$ \\
Spanish noncognates & 1192 & 309 & 969 & 184 & $p<.05$ \\
Spanish cognates & 1190 & 310 & 983 & 167 & $p<.05$ \\
Portuguese noncognates & 1645 & 573 & 1308 & 280 & $\mathrm{p}>.05$ \\
Portuguese cognates & 1565 & 473 & 1321 & 271 & $\mathrm{p}>.05$ \\
Spanish pseudowords & 1707 & 599 & 1560 & 299 & $\mathrm{p}>.05$ \\
Portuguese pseudowords & 1617 & 498 & 1392 & 280 & $\mathrm{p}>.05$ \\
German words & 1276 & 331 & 1118 & 221 & $\mathrm{p}>.05$ \\
Basque words & 1320 & 356 & 1223 & 231 & $\mathrm{p}>.05$ \\
\hline
\end{tabular}

Source: The Author (2020).

When using a one-way ANOVA to compare accuracy levels, the native/heritage trilingual group was more accurate in all word conditions. A main effect was observed for language group on Spanish noncognates at the $p<.05$ level for word condition $[F(1,64)=9.62, p<.05]$ and on Spanish cognates $[F(1,64)=10.6, p<.05]$ as well. The results also showed a significant effect on Portuguese noncognates at the $p<.05$ level $[F(1,64)=12.5, p<.05]$, and Portuguese cognates $[F(1$, $64)=14.6, p<.05]$. The same pattern was also found for Spanish pseudowords $[F(1,64)=13.03$, $p<.05]$ and Portuguese pseudowords $[F(1,64)=13.5, p<.05]$ as a main effect was also seen. Lastly, significant effects were also presented in the German word condition $[F(1,64)=3.86, p<.05]$ and Basque as well $[F(1,64)=4.52, p<.05]$. To summarize, results show the native/heritage speaker trilingual group was more accurate in all conditions.

Table 3. Means in Accuracy (\%) for Native/Heritage and Nonnative Trilingual Speakers by Word Condition.

\begin{tabular}{lccccc}
\hline Word Condition & Non-Native Accuracy & Std. Dev. & Native Accuracy & Std. Dev. & $p$ \\
\hline Spanish noncognates & $81.3 \%$ & .1518 & $93.9 \%$ & .0680 & $p<.05$ \\
Spanish cognates & $83.8 \%$ & .1290 & $95.1 \%$ & .0569 & $\mathrm{p}<.05$ \\
Portuguese noncognates & $50.0 \%$ & .2473 & $73.9 \%$ & .1522 & $\mathrm{p}<.05$ \\
Portuguese cognates & $50.3 \%$ & .2503 & $76.7 \%$ & .1671 & $\mathrm{p}<.05$ \\
Spanish pseudowords & $51.5 \%$ & .2527 & $76.8 \%$ & .1840 & $\mathrm{p}<.05$ \\
Portuguese pseudowords & $56.3 \%$ & .2499 & $82.1 \%$ & .1911 & $\mathrm{p}<.05$ \\
German words & $90.5 \%$ & .1046 & $96.2 \%$ & .0732 & $\mathrm{p}<.05$ \\
Basque words & $85.8 \%$ & .1326 & $93.3 \%$ & .0516 & $\mathrm{p}<.05$ \\
\hline
\end{tabular}

Source: The Author (2020).

\section{Discussion}

The current research focused on exploring the nature of trilingualism in regard to word processing between typologically similar languages as well as different proficiency levels. It looked 


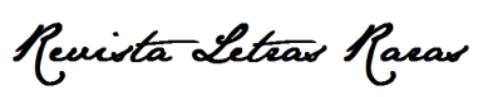

ISSN: 2317-2347 - v. 9, n. 4 (2020)

Todo o conteúdo da RLR está licenciado sob Creative Commons Atribuição 4.0 Internacional

at word processing by Spanish (L1) - English (L2) - Portuguese (L3) trilingual speakers in comparison to English (L1) - Spanish (L2) - Portuguese (L3) trilingual speakers. The major questions guiding the present study were: When trilinguals recognize words in Spanish, what is the impact of also knowing another typologically similar language (L3 - Portuguese)? Does the degree of proficiency in Spanish enable learners to better control lexical activation in L3 - Portuguese?

As seen above, native/heritage Spanish trilingual speakers processed words faster in Spanish in comparison to nonnative trilingual speakers. In addition, they were also more accurate throughout all word conditions. These results demonstrate that higher proficiency levels may benefit processing speed, but it specially contributes to higher accuracy in distinct word conditions. Based on the present results, proficiency seems to be a key element that enables trilinguals to develop a refined categorization mechanism in order to handle a multilingual lexicon. However, the higher cognitive load to process a typologically similar language such as Portuguese still remains because the native/heritage trilingual group did not process words in Portuguese significantly faster than the nonnative trilingual group. In other words, language proficiency plays a positive role in accuracy. The ability to control the simultaneous process of different languages in the mind seems to expand with language proficiency regardless of the typological differences among languages. The word processing cognitive costs still remain, but proficiency allow learners to have higher control on their lexicon in different languages.

Because accuracy results for words such as Portuguese noncognates (50.0\% and $73.9 \%$ ) and Spanish pseudowords (51.5\% and $76.8 \%)$ presented similar values by the non-native and native/heritage trilingual groups respectively, it is relevant to explore whether these words have been processed similarly in the trilingual mind. By looking at the values of Portuguese pseudowords in terms of accuracy (56.3\% and $82.1 \%$ ), we can see both groups perform more accurately. Therefore, participants are able to process Portuguese pseudowords more accurately than Spanish pseudowords because semantic values are not activated. To recall, the difference between real and pseudowords is the level of lexical layers it triggers in the processing of lexical activation. In the case of pseudowords, no semantic level is activated as the word is not real. As in the case of Spanish pseudowords, although semantics do not play a role in processing, formal similarities between real and pseudowords in Spanish might have slowed participants when considering such tokens as actual real words in Spanish. Lastly, for noncognates, the structural competition is not present, as in comparison to cognates, but the semantic value of the lexical token is activated because it represents a real word in the bilingual/ trilingual mind. 


\section{Peucista Leteas Maras \\ ISSN: 2317-2347 - v. 9, n. 4 (2020) \\ Todo o conteúdo da RLR está licenciado sob Creative Commons Atribuição 4.0 Internacional}

Besides language proficiency, the order of language acquisition per se, might influence word processing. The native/heritage trilingual group has first learned Spanish and developed proficiency in a nonnative and non-typologically similar language (English) before learning another typologically similar language (L3 - Portuguese). As a result, learning structurally-influential languages apart from each other may have facilitated word processing in Spanish by the native/heritage trilingual group.

The present study results might also shed light to possible pedagogical implications on the teaching of typological similar languages such as Portuguese and Spanish. Currently, (native and nonnative) Spanish speakers seeking to learn Portuguese in the United States are assigned to take accelerated Portuguese courses. This decision relies on the fact that the extensive structural similarities between Spanish and Portuguese will speed the language learning process in Portuguese. However, this is not always the case. In fact, Montrul (2004) has demonstrated that the strong language transfer between Spanish and Portuguese may unfavor the acquisition of $L 3$ - Portuguese. The results presented previously support this claim because Spanish speakers did not seem to have benefited from Spanish structural similarities to process Portuguese words faster. Language learners trying to acquire typologically similar languages have specific linguistic needs that can be best addressed through effective and tailored language teaching methodologies.

\section{Conclusion}

The present study looked at the interaction between language typology, proficiency and trilingualism per se. It confirms a rather predictable pattern that native/heritage trilingual speakers are indeed able to process Spanish words faster and more accurately than nonnative Spanish trilingual speakers. However, the linguistic proximity between Spanish and Portuguese has not showed to benefit native/heritage Spanish trilingual speakers to process Portuguese words faster than nonnative Spanish trilingual speakers. On the other hand, higher levels of bilingual proficiency in Spanish (L1) and English (L2) has enabled trilinguals to have higher levels of control over lexical processes in languages such as Portuguese, German and Basque.

This study can also prompt language educators to start a dialogue over effective language teaching practices that can facilitate the acquisition of typologically similar languages such as Spanish and Portuguese. As seen above, linguistic proximity does not automatically result in 


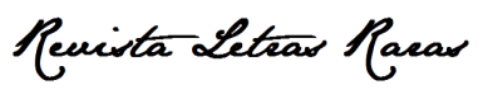

ISSN: 2317-2347 - v. 9, n. 4 (2020)

Todo o conteúdo da RLR está licenciado sob Creative Commons Atribuição 4.0 Internacional

linguistic transfer and consequently language acquisition. On the contrary, studies have shown such similarities to impact language acquisition in a detrimental way (MONTRUL, 2004). Future studies are needed to advance on the investigation about the nature of trilingualism and to explore different linguistic and non-linguistic elements that can directly promote or hinder lexical processes in different languages.

\section{References}

CASAPONSA, A. CARREIRAS, M. DUÑABEITIA, J. A. How do bilinguals identify the language of the words they read? Brain Research, vol 1624, p. 153-166, 22 Out 2015.

DE GROOT, A. M. B. Language and Cognition in Bilinguals and Multilinguals: An Introduction. New York: Taylor and Francis, 2011.

DIJKSTRA, A. VAN HEUVEN, W. J. B. The architecture of the bilingual word recognition system: From identification to decision. Bilingualism: Language and Cognition, vol 5, p.175-197, 18 Dez 2002.

EBERHARD, D. M. GARY, F. SIMONS, C D. FENNIG (eds.). 2020. Ethnologue: Languages of the World. Twenty-third edition. Dallas, Texas: SIL International, 2020. Disponível em: https://www.ethnologue.com. Acesso em: 6 dez 2020.

FORCELINI, J. SUNDERMAN. G. When More is Less: The Effect of a Third Language on a Second Language. Hispania, vol 103, no 4, p. 489-500. Disponível em: doi:10.1353/hpn.2020.0110. Acesso em: 22 Dec. 2020.

MALKIEL, Y. Difficulties in the Simultaneous Study of Spanish and Portuguese. The Modern Language Journal, vol. 25, no. 11, p. 853-856. 1941. Disponivel em: www.jstor.org/stable/317132. Acesso em: 7 Dec. 2020.

MONTRUL, S. Dominant language transfer in Spanish L2 learners and heritage speakers. Special issue of Second Language Research, vol 26, p. 293-327, 9 Jul 2010.

MONTRUL, S. Subject and object expression in Spanish heritage speakers: a case of morphosyntactic expression, Bilingualism: Language and Cognition, vol 7, no 2, p.125-142, 23 Jul 2004.

VAN HELL, J. DE GROOT, A. Conceptual representation in bilingual memory: Effects of concreteness and cognate status in word association. Bilingualism: Language and Cognition, vol. 1, no. 3, p. 193-211, Dez 1998.

VAN HESTE, T. Visual word recognition in bilinguals. 1999, dissertação (mestrado em linguística e literatura) Universidade de Leuven, Bélgica.

VAN HEUVEN, W. J. B. DIJKSTRA, A. The architecture of the bilingual word recognition system: From identification to decision. Bilingualism: Language and Cognition, vol. 5, no 3, p.175-197, Dez 2002. 


\section{Penista Letras Paras}

ISSN: 2317-2347 - v. 9, n. 4 (2020)

Todo o conteúdo da RLR está licenciado sob Creative Commons Atribuição 4.0 Internacional

VAN HEUVEN, W. J. B. DIJKSTRA, A. The BIA model and bilingual word recognition. In J. Grainger \& A. M. Jacobs (Eds.), Localist connectionist approaches to human cognition, Mahwah, $\mathrm{NJ}$ : Erlbaum, p. 189-225, 1998.

VAN HEUVEN, W. J. B. DIJSTRA, A. GRAINGER, J. Orthographic neighborhood effects in bilingual word recognition. Journal of Memory and Language, vol 39, no 2 p. 458-483, Ago 1998. 